\title{
The Influence of the Microenvironment on Company Value with the Macro Environment as a Moderator Variable of the Pharmaceutical Sub-Sector Listed on IDX
}

Fhiska $^{1 *}$, Augustina Kurniasih ${ }^{1}$

${ }^{1}$ Magister of Management, Universitas Mercu Buana, Jakarta, Indonesia

DOI: $10.36348 /$ sb.2022.v08i01.006 $\quad$ | Received: 15.12 .2021 | Accepted: 21.01 .2022 | Published: 29.01 .2022

*Corresponding author: Fhiska

Magister of Management, Universitas Mercu Buana, Jakarta, Indonesia

\section{Abstract}

This study purposed to determine the impact of the microenvironment on firm value with the macro environment as the moderator variable. This research population is the pharmaceutical sub-sector companies listed on the Indonesia Stock Exchange in terms 2015-2020. Samples that suit the criteria are eight companies. The data were analyzed using panel data regression with a multiplication interaction structure so that there were 48 observations. The results showed that the Fixed Effect is the best model. The study results simultaneously show that the microenvironment is measured using investment decision variables, market penetration, and inventory turnover. The macro-environment, as measured using the GDP variable, has a significant and positive effect on firm value. Partly, investment decisions and inventory turnover have a positive and significant effect on firm value, while market penetration has no impact on firm value. Meanwhile, GDP can only moderate investment decisions and inventory turnover and not moderate market penetration.

Keywords: Investment decisions, market penetration, inventory turnover, GDP, firm value, Pharmaceutical sub-sector industry.

Copyright (9) 2022 The Author(s): This is an open-access article distributed under the terms of the Creative Commons Attribution 4.0 International License (CC BY-NC 4.0) which permits unrestricted use, distribution, and reproduction in any medium for non-commercial use provided the original author and source are credited.

\section{INTRODUCTION}

Technological developments and the era of globalization have brought an increasingly competitive global environment (Adamik \& Sikora-Fernandez, 2021). Companies are forced to compete fiercely to maintain a competitive advantage (Porter, 2007) and contribute to the country's development (ILO, 2015). The pharmaceutical sub-sector industry, including the non-oil and gas manufacturing industry, is the fourth biggest contributor to the national economy. According to Deloitte (Deloitte, 2021), the healthcare industry is the most competitive industry globally. This can be seen from the community's concern, interest, and purchasing power towards the importance of health even in challenging economic conditions. The pharmaceutical sub-sector is an engine of economic growth with a solid potential to play an important role in Indonesia's industrial landscape. In America, the pharmaceutical industry's revenue increased to 517 trillion dollars (EFPIA, 2012). According to the Ministry of Industry and Trade (2020), the pharmaceutical industry in Indonesia has increased significantly and is among the most competitive industries during a pandemic (Kemenperin, 2020). During the 2020 Covid-19 pandemic, the pharmaceutical industry grew positively and contributed 0.17 percent to the Indonesian economy (BPS, 2021). The two countries, which are developed countries and emerging market and developing economies (EMDE), have a competitive pharmaceutical sector.

According to Fidhayatin and Dewi (Fidhyatin \& Dewi, 2012), the value of the company is a publiclytraded company can be seen through the value of shares traded at a specific price. Investors will see how the company's ability is by seeing how appropriate the share price is in the portion of its ownership. The market forms stock prices as a reflection of the company value, which can be used as a proxy in an effort to measure the company value. Good corporate value is able to provide prosperity for shareholders. The 


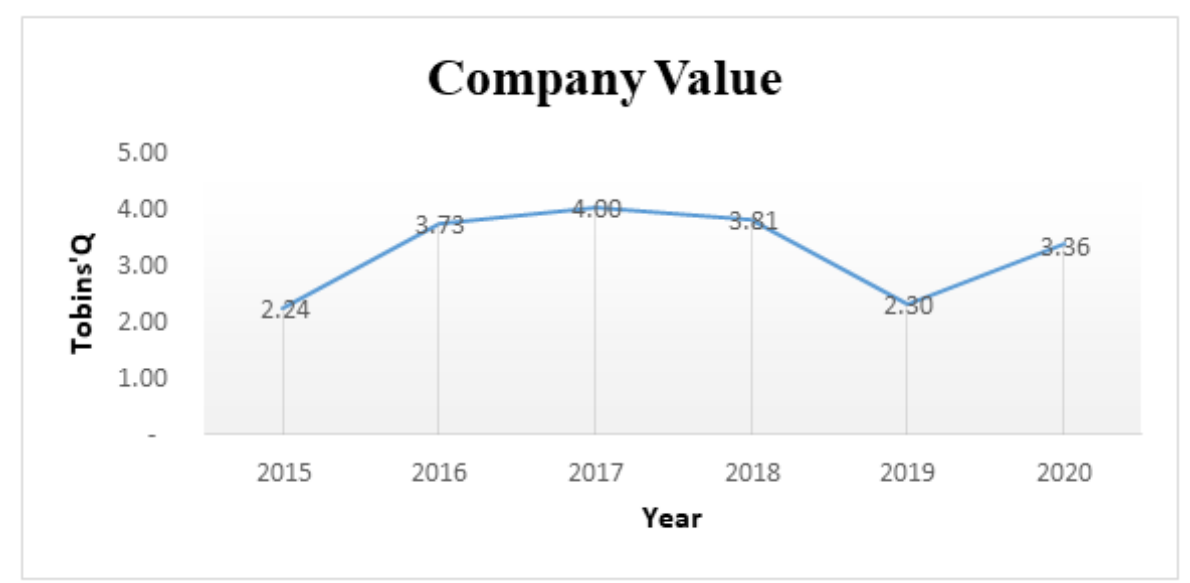

Figure 1: Company Value in the Pharmaceutical Sub-Sector for the 2015-2020 Period Source: IDX (2021)

Figure-1 points that the value of the company during the last five years has fluctuated movements. In 2015 the value of pharmaceutical sector companies experienced a downward trend compared to the following years. In 2015, the beginning of the global economic slowdown affected the decline in company value (CRS, 2021) to 2.24 (IDX, 2021), where the biggest impact was felt, namely the pharmaceutical subsector (Kumparan, 2018). The company value in 2015 was still worse than in 2019. The lowest company value in 2015 was owned by TSPC with a value of 0.36 and the highest from MERCK at 4.99. However, in 20162017 began to experience an increase where the highest company value was owned by INAF of 11.08 and steadily increased in 2017-2018 with the same value of 14.62. In 2016, the value of the pharmaceutical subsector companies increased by 1.49 (IDX, 2021). Furthermore, it experienced a downward trend again in 2018-2019, but in 2020 began to experience recovery again with a reasonably high increase reaching 3.36 , but still unable to compete with the company value in 2017 of 4.00 .

According to Nurlela \& Islahuddin (Nurlela \& Islahudin, 2008), company value is a necessary indicator for investors to assess the whole company. The high corporate value will increase the public perception that the company's performance is also in a better condition; therefore, the company will be able to fulfill the wishes of shareholders by providing prosperity. Measurement of company performance, according to Sindhu (Sindhu et al., 2016), can use Tobin's Q, so it can be concluded that Tobin's Q can be used as a parameter of company measuring instrument in seeing the value of a company. According to Kotler and Armstrong (Kotler \& Keller, 2016), company performance is influenced by six components of the microenvironment, namely companies, consumers, suppliers, competitors, marketing, and the public. However, companies, consumers, and suppliers are the most important components in building company value (Holm et al., 2012).

The company can be noticed from how the company makes investment decisions (Vranakis \& Chatzoglou, 2011) so that it can show that the company is able to manage/allocate funds to acquire and upgrade business/investment appropriately. Ayem \& Nugroho (Ayem \& Nugroho, 2016) and Wahyuati \& Safitri (Wahyuati \& Safitri, 2015) point the results of research that investment policies have a positive and significant impact on firm value. In contrast to Fauziah \& Asandimitra (Fauziah \& Asandimitra, 2018), which shows the results that investment decisions have no effect on firm value.

Another component that is also important as an indicator is the consumer component (Holm et al., 2012). Companies need to orient themselves to consumers to be able to dominate the market (Adams et al., 2019). It aims to increase consumer purchasing power and sales of company products or services (Adams et al., 2019). The company's skills in controlling consumers or markets can be analyzed through market penetration (Subramanyam, 2014). Market penetration will show the company's position in terms of product sales. The bigger the market share by the company, the bigger the company's performance (Muriithi \& Paul, 2020; Mwangi \& Gakobo, 2018). This means that when the company orientates itself to consumers, it will experience an increase in its market size, with high sales income indicating that the condition of the company's value also increases. In addition, market penetration has a positive impact on company growth (Nduki, 2016; Numa, 2013). Companies that have good growth rates show that the company has good values as well.

Suppliers play an important role in the company chain, where suppliers can be assessed 
Fhiska \& Augustina Kurniasih., Sch Bull, Jan, 2022; 8(1): $42-53$

through inventory turnover (Subramanyam, 2014). Inventory turnover is a financial ratio that indicate how much the company sells and replaces its inventory in a certain term (Kieso et al., 2011). Inventory turnover that is too small indicates weak company sales and a slow supply of goods to the company, and vice versa (Kieso et al., 2011; Subramanyam, 2014)

During a pandemic, capital markets tend to be more volatile and move very uncertainly (Mishra \& Mishra, 2020). Market behavior is difficult to predict and has a downward trend, although in some sectors, it can persist or even increase. The pandemic brought a strong blow to capital markets in developing countries (Mishra \& Mishra, 2020), particularly in Indonesia (Rahmayani \& Oktavilia, 2020). In addition, global economic stability has experienced shocks and recessions in many countries (World Bank, 2020) including Indonesia, so this research is important to do to see how the influence of the company's microenvironment on company value by considering the company's macroenvironment before making decisions on the company's microenvironment. This is because the macro environment has a big influence when the situation is full of uncertainty (McKinsey, 2021) . According to Banik and Roy (Banik \& Roy, 2021), an important aspect in measuring the macro environment is seen from GDP. This is because the determinants of GDP are weighed from the political, economic, social, technological, ecological and legal aspects. This macro-environmental aspect can represent the state of a country as well as the impact of the pandemic. Banik and Roy (Banik \& Roy, 2021) prove that GDP has a share in trading performance. The company's macro environment is beyond the company's control and is uncertain, so it will greatly influence the role of the company's microenvironment in increasing the value of the company (Mbithi et al., 2017).

\section{LITERATUR REVIEW}

Signaling theory (Michael, 1973) explains the information that the owner wants to provide with a signal or signal in the form of information that reflects the state of a company where the information will be useful for investors.

Asymmetry information theory (Akerlof, 1970) assumes that the parties involved in the company do not have inline information but only certain parties who are able to have better information than other parties, both regarding the chance and risks of the company in the future.

Open system theory (Cumming \& Worley, 2005 ) is another approach taken by open systems by showing that decisions and actions within an organization must look at their environmental conditions, both as an important source of input and as an outlet for absorbing output because the organization needs information from their external environment regarding government regulations, supplier relationships or dependence on varied external constituencies to exercise good control in continuing their existence (Robbins \& Coulter, 2012).

Firm value is a value that describes how much price investors pay if the company is sold (Husnan \& Pudjiastuti, 2012). The main aim of establishing a company is to optimize the value of the company by maximizing the prosperity of its shareholders. The better the company value, the level of prosperity of the owner of the company will also be greater (Wiagustini, 2013). The high value of the company is considered a necessary thing for investors because it is used as an indicator in assessing the company as a whole (Nurlela \& Islahudin, 2008).

Investment decisions are one of the financial management functions that involve the allocation of funds sourced from and within outside the company with the aim of obtaining profits in the future (Kurniasih \& Ruzikna, 2017). According to Sutrisno (Sutrisno, 2009), investment decisions are the duties of financial managers who are carried out routinely to regulate the flow of funds so that the company's operations run well and are fully responsible for making investments decisions for the company's survival in the future.

Market penetration is an effort to escalate company sales without leaving the original market strategy of a product. This is the first growth strategy that is pursued in general by companies with the intention to grow (Mutia, 2013). Through this strategy, a company develops into a marketplace where the products is already exist with the aim of selling more to current customers

Inventory turnover is a financial ratio that shows the number of times that company has replaced and sold inventory during a certain term (Subramanyam, 2014). A low level of inventory turnover may indicate overstock (Subramanyam, 2014), obsolescence, or shortages in production or marketing lines (Kieso et al., 2011). However, in some cases, it is explained that higher inventory levels occur in anticipation of rapid price increases or expected market shortages (Kieso et al., 2011).

GDP can measure the monetary value of final goods and services purchased by end-users which are produced in a country in a certain period. In the economy of a country, there are indicators that are used to assess whether the economy is going well or not. Indicators in assessing the economy can use nominal GDP because it is able to reflect current economic conditions. In addition, it can be used to compare 
Fhiska \& Augustina Kurniasih., Sch Bull, Jan, 2022; 8(1): $42-53$

between countries to see how much contribution is made by the countries that carry out international trade.

\section{Hypothesis}

Based on mentioned theoretical studies and supported by previous research, the hypotheses of this study are as follows:

Hypothesis 1: Investment decisions have a positive effect on firm value

Hypothesis 2: Market penetration has a positive effect on firm value
Hypothesis 3: Inventory turnover has a positive effect on firm value

Hypothesis 4: GDP can moderate investment decisions on firm value

Hypothesis 5: GDP can moderate market penetration of firm value

Hypothesis 6: GDP can moderate inventory turnover on firm value

The framework of this research is as follows:

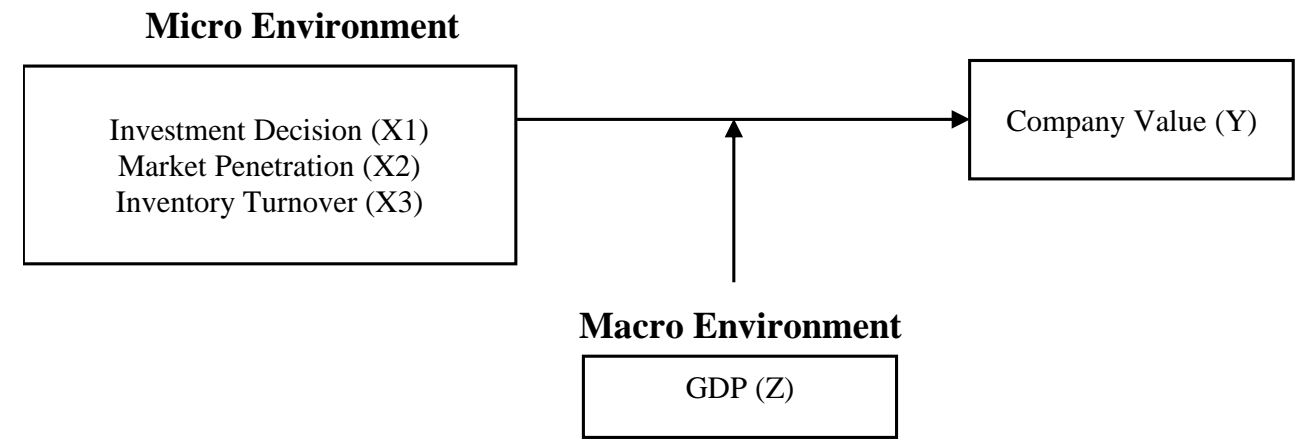

Figure 2: Conceptual Framework

\section{RESEARCH METHOD}

This research is one of the causality research type. This research use a quantitative approach. The research data are annual data for 2015-2020 from eight companies (cross-section). Data analysis used a panel data regression approach with a total of 48 observations. The research population is all pharmaceutical sub-sector companies listed on the Indonesia Stock Exchange in 2021 or ten companies in total. Companies that meet the sample criteria are eight companies.

The regression equation that used to answer this research problem is:
TOBINSQ $_{\text {it }}=+{ }_{1}$ Inv_dec $_{\text {it }}+{ }_{2}$ Mark_Pent it $_{3}$ IT $_{\text {it }}+$ ${ }_{4}$ GDP $_{\text {it }}+{ }_{5} \mid$ Inv_dec $_{\text {it }} *$ GDP ${ }_{\text {it }}\left|+{ }_{6}\right|$ Mark_Pent $_{\text {it }} *$ *GD $\mathbf{P}_{\text {it }}\left|+{ }_{7}\right| \mathbf{I T}$ it $* \mathbf{G D P} \mathbf{P}_{\text {it }} \mid+{ }_{\text {it }}$

Where:

$=$ intercept

$=$ regression coefficient

TOBINSQ $=$ Pharmaceutical Company Value

Inv_Dec $=$ Investment Decision

Mark_Pent $=$ Market Penetration

IT = Inventory Turnover

GDP = Gross Domestic Product

it $=$ error term

\section{RESULT AND DISCUSSION}

Table-1: Descriptive Statistics of Research Variables

\begin{tabular}{|l|l|l|l|l|l|}
\hline & $\mathbf{N}$ & Minimum & Maximum & Mean & Std. Deviation \\
\hline Inv_dec (X1) & 48 & -.069 & .989 & .149 & .200 \\
\hline Mark_Pent (X2) & 48 & .017 & 0.609 & .171 & .195 \\
\hline IT (X3) & 48 & 1.308 & 8.980 & 3.639 & 1.436 \\
\hline GDP (Z) & 48 & 11.414 & 11.849 & 11.647 & .1412 \\
\hline TOBIN'S Q (Y) & 48 & .080 & 14.623 & 3.240 & 3.069 \\
\hline
\end{tabular}

Source: Eviews 12

The average value of investment decisions is 0.149 , which means it has an increase in fixed assets of $14.9 \%$. The minimum value of the investment decision variable is $6.9 \%$ in MERCK companies in 2019. MERCK has decreased due to the divestment of the over-the-counter medicine or consumer health business, causing export sales to decline; thus, the assets owned by the company have not experienced good growth and have not can reach the maximum target. The maximum value of the investment decision variable of $98.9 \%$ occurred in 2020 from the PYFA company. The impact of the Covid-19 pandemic has prompted PYFA to be committed to meeting the needs of the community, namely by focusing on developing products for 
Fhiska \& Augustina Kurniasih., Sch Bull, Jan, 2022; 8(1): 42-53

consumer health, selling medical devices, and actively exploring collaborations with trusted companies in the healthcare sector, so that the performance growth of $98.9 \%$ is considered very satisfactory where the results from sales medical device products that experienced a sharp increase.

The average market penetration value is 0.171 , which means that the ratio of sales revenue per company in the pharmaceutical sub-sector to its market industry is $17.1 \%$ or in other words, each company has more significant sales revenue than sales revenue for the pharmaceutical sub-sector industry. Sales revenue or sales revenue shows the income earned by the company exclusively from the sale of services or goods. The greater the level of income obtained, the higher the level of company efficiency. The minimum market penetration variable value is $1.7 \%$ for the PYFA company in 2019. PYFA's sales have decreased due to discounts on sales returns and discounts made by the company to attract consumers to some products that are close to expiration so that they can still be sold. In addition, the market segment of PYFA comes from prescription drugs that are generally used while the public has started to switch to consuming drugs from the National Health Insurance program while PYFA failed to contribute to the program. The maximum value of the market penetration variable for KLBF companies in 2017 was $60.9 \%$. KLBF was able to show a positive performance, namely achieving the company's target from the sales performance of the nutrition division and the consumer health division. Selling internal products driven by volume growth in line with intensive marketing activities and distribution penetration is the KLBF's strategy.

The average value of inventory turnover is 3,639 , which means that it has an inventory turnover activity level of 3,639 times in a period. Where the more the inventory turnover, the more the profit generated. The minimum value of the inventory turnover variable is 1,308 times that of MERCK companies in 2020. In 2020, it caused IVF treatment clinics to be closed due to the Covid-19 pandemic, so that inventory turnover was not able to generate income quickly and MERCKs were still not optimal in their efforts to penetrate on fertility products or fertility drugs, which are one of their superior products. The maximum value of inventory turnover is 8,980 times that of the INAF company in 2020. INAF is maximizing business opportunities for medical devices, medicines, and health services during the Covid-19 pandemic by achieving drastic sales of up to $183.30 \%$ year on year (YoY).

The average GDP value of 11,647 means that the overall GDP value in the pharmaceutical sub-sector for the 2015-2020 period has an average amount of $11.65 \%$ per year. This implies that the higher the income of the community, the better the GDP. The minimum value of the GDP variable of $11.41 \%$ occurred in 2015. In 2015 there was a slowdown in the global economy, mainly the slowdown in the Chinese economy, which resulted in commodity prices ruin to a low position. As a large commodity exporter, Indonesia has had its export performance disrupted and has an impact on Indonesia's national income (GDP). The maximum value of the GDP variable is $11.85 \%$ in 2019 . The pharmaceutical industry in Indonesia in 2019 grew two times compared to 2018 (Kemenperin, 2020). This achievement came from the economic income of $4.97 \%$ in the fourth quarter of 2019 and GDP reaching Rp 22.26 trillion. Furthermore, followed by achievements throughout 2019, the export value of pharmaceutical industry products has increased compared to the gains in the previous year. In addition, in the fourth quarter of 2019, the GDP of the European Union showed an increase of $0.2 \%$, where it can be said that between the two countries that carry out international trade, they have good economic conditions.

The company average value is 3,240, which implies that the average market value of the pharmaceutical sub-sector companies for the 2015-2020 period is valued at 3,240 times greater than the book value. Tobins'Q value above 1 indicates that the company is able to maximize market value. The greater the value of Tobins' $Q$ shows that there is market confidence in the company, so the higher the company value can be reflected in the value of its Tobins'Q. The minimum value of the SIDO company value variable in 2018 is 0.080 times. The company has not been able to maximize its market value because it shows a Tobins'Q value below 1 . The maximum value of INAF's company value variable in 2018 is 14,623 times, where INAF shows that it is able to maximize its market value with a Tobins'Q value of $14,623>1$.

The table below presents the results of selecting the best panel model. In this study, it was found that the best estimation model is the Fixed Effect Model (FEM). 
Fhiska \& Augustina Kurniasih., Sch Bull, Jan, 2022; 8(1): $42-53$

Table-2: Best Panel Model Selection Results

\begin{tabular}{|c|c|c|c|}
\hline Test & Decision-making & $\begin{array}{c}\text { The } \\
\text { calculation } \\
\text { results }\end{array}$ & Conclusion \\
\hline Chow test & $\begin{array}{l}\text { If (Prob.) for Cross-section F. } \\
>0.05, \mathrm{CE} \text { is selected. If } \\
\text { (Prob.) } \\
\text { section F. }<0.05 \text {, FE is selected. }\end{array}$ & $\begin{array}{l}\text { (Prob.) for } \\
\text { Cross-section } \\
F \quad=\mathbf{0 . 0 0 0 0}< \\
0.05\end{array}$ & FEM \\
\hline Hausman test & $\begin{array}{l}\text { If (Prob.) for random cross- } \\
\text { section }>0.05, \quad \mathrm{RE} \text { is } \\
\text { selected. If } \quad \text { (Prob.) for } \\
\text { a random cross-section }<0.05 \text {, } \\
\text { FE is chosen. }\end{array}$ & $\begin{array}{l}\text { (Prob.) for } \\
\text { Cross-section } \\
F \quad=\mathbf{0 . 0 0 7 2}< \\
0.05\end{array}$ & FEM \\
\hline
\end{tabular}

The best model test results point the appropriate model. The calculated $\mathrm{F}$ value is 28.3402 with a probability of 0.0000 . The ability of that model to explain the phenomenon of the problem is $89.06 \%$. The remaining $10.94 \%$ is explained by variables other than the model.

Table-3: Fixed Effect Model (FEM) Analysis Table

\begin{tabular}{|l|l|c|c|c|}
\hline Variable & Coefficient & t- Statistics & Prob. & Note. \\
\hline C & 261.7240 & 3.6490 & 0.0009 & \\
\hline Inv_Dec & 270.6977 & 3.8038 & 0.0006 & $*$ \\
\hline Mark_Pent & 18.6766 & 0.6325 & 0.5314 & \\
\hline IT & 58.2578 & 3.5384 & 0.0012 & $*$ \\
\hline GDP & 22.2026 & 3.7744 & 0.0006 & $*$ \\
\hline MRA1 & 23.2858 & 3.8421 & 0.0005 & $*$ \\
\hline MRA2 & -1.4752 & -0.6774 & 0.5029 & \\
\hline MRA3 & 4.9550 & 3.5386 & 0.0012 & \\
\hline$R^{2}$ & 0.9232 \\
\hline$R^{2}$ adjusted & 0.8906 \\
\hline F-statistics & 28.3402 \\
\hline Prob(F-statistics) & 0.0000 \\
\hline
\end{tabular}

Based on Table- 3 the regression equation for the panel data in this study are:

Tobin's $Q=261.7240+270.6977$ Inv_Dec $+\mathbf{1 8 . 6 7 6 6}$

Mark_Pent + 58.2578 IT + 22.2026 GDP + 23.2858 MRA1 - 1.4752 MRA2 + 4.9550 MRA3

The constant is 261.7240 with a significance of 0.0009. This means that when investment decisions, market penetration, inventory turnover, and GDP are zero (doesn't affect), the Tobins'Q value of the pharmaceutical sub-sector is 261,7240 times.

The regression coefficient value of the investment decision variable is 270.6977 , with a significance of 0.0006 . This shows that investment decisions have a significant and positive effect on firm value, ceteris paribus. If fixed assets increased by one percent, then the company value (as measured by Tobins'Q) would increase by $270.70 \%$.

The regression coefficient value of the market penetration variable is 18.6766 , with a significance of 0.5314. This shows that market penetration has no significant but positive effect on firm value.
The regression coefficient value of the inventory turnover variable is 58.2578, with a significance of 0.0012 . This implies that inventory turnover has a significant and positive effect on firm value, ceteris paribus. If each inventory turnover increased by one unit, the firm's value (as measured by Tobin's Q) would increase 58.26 times, ceteris paribus.

The coefficient value of the GDP variable is 22.2026 with a significance of 0.0006 . This shows that GDP has a significant and positive effect on firm value. The GDP that increases can also increase the purchasing power of consumers towards the company's products. The increasing purchasing power of the people can increase the company's sales. Companies that experience increased sales will increase the company's value. If GDP increases by one percent, then the firm value (as measured by Tobins'Q) will increase by $23.20 \%$.

The investment decision coefficient value variable and GDP (MRA1) is 23.2858, with a significance of 0.0005 . That is, GDP acts as a quasimoderation because GDP has a direct impact on firm value and can strengthen the influence of investment 
Fhiska \& Augustina Kurniasih., Sch Bull, Jan, 2022; 8(1): 42-53

decisions on firm value, ceteris paribus. The regression coefficient value means that if there is an increase in investment decisions and GDP by one percent, the firm value (as measured by Tobins'Q) will increase by $23.28 \%$.

The coefficient value of market penetration and GDP (MRA2) variables is -1.4752 with a significance of 0.5029 . This means that GDP does not act as a moderator of the market penetration influence on firm value.

The value of the variable coefficient of inventory turnover and GDP (MRA3) is 4.9550 with a significance of 0.0012 . That is, GDP acts as a quasimoderation because GDP directly affects the value of the firm and can strengthen the effect of inventory turnover on firm value, ceteris paribus. The regression coefficient value points that if there is an increase in inventory turnover and GDP by one unit, the firm value (as measured by Tobins'Q) will increase by 4.95 times.

\section{DISCUSSION OF RESEARCH RESULTS}

\section{1) The Investment Decisions Effect on Firm Value}

The results show that investment decisions have a significant and positive effect on firm value. According to Hidayat (Hidayat, 2010), investment decisions are a necessary factor in the company's financial function to achieve the company's goal of maximizing shareholder prosperity through company investment activities to obtain a large level of profit with a certain level of risk so that it is expected to increase the company value.

Najmudin (Najmudin, 2011), investment in fixed assets is the company's hope to be able to get back the funds that have been invested. Investment decisions affect the company value if the company can show investors that the company is making the right investment decisions. Myers (Myers \& Majluf, 1984) explains that the direct effect of investment decisions on firm value is obtained from the activity of investment itself through project selection or other policies such as creating new products, replacing more efficient machines, developing research and development. This is in line with signaling theory (signal theory), where high investment activities are able to capture positive signals for investors in giving confidence to the company to develop prospects and company growth so that it will have an impact on increasing company value.

This finding is the same with research by Ayem \& Nugroho (Ayem \& Nugroho, 2016) examining the manufacturing industry in Indonesia, which was listed on the IDX for the term 2010-2014, Wahyuati \& Safitri (Wahyuati \& Safitri, 2015), who examined cement companies listed on the IDX in 2009-2013 period, Afzal \& Rohman (Afzal \& Rohman, 2012) which examines manufacturing companies listed on IDX for the term 2007-2010. However, this research is not in line with Fauziah \& Asandimitra (Fauziah \& Asandimitra, 2018), who researched chemical companies listed on IDX for the term 2012-2016, and Yuliani \& Hadi (Yuliani \& Hadi, 2020), who examined the property sub-sector in IDX for the period 20142019.

\section{2) Effect of Market Penetration on Firm Value}

The study results indicate that market penetration has no impact on firm value. Market penetration strategy is the most effective marketing strategy used in a competitive market, which can be used by companies to attract new customers and or increase the use of existing products and services (Kotler \& Keller, 2016).

Slater and Narver (Slater \& Narver, 1995), market penetration strategies involve existing products and services. Therefore, the aim of the market penetration strategy is to focus on increasing the market share of the product or service currently on the market. Levay (Lévay et al., 2017), companies adopt a market penetration strategy to increase revenue from sales without changing services or products. The penetration mode choice is made at the company level, which is a strategic decision for the company in increasing the value of the company. However, the results are not in line with Muriithi \& Waithaka (Muriithi \& Paul, 2020), who researched agrochemical companies in Kenya where market penetration had a positive effect on firm value. The market penetration strategy has not been properly used in this study. Companies must be required to continue to be able to compete in creating products or services by always adjusting to the needs of the community or market conditions in order to increase high sales to generate profits so that it will have an effect on increasing the company value. The results of this study indicate that the market penetration strategy has not been able to increase firm value. If the company has been able to develop new markets and/or products, then the company needs to maintain these markets so that consumers remain satisfied and loyal. Customer satisfaction and loyalty will increase company sales and ultimately increase company value.

\section{3) Influence of Inventory Turnover on Firm Value}

The study results indicate that inventory turnover has a positive and significant effect on firm value. Inventory is a crucial asset component because it is a very valuable part of current assets. Excess or lack of inventory is a bad symptom, so it is important for companies to determine the right proportion of inventory (Brigham \& Houston, 2013). Companies need to ensure inventory turnover to maintain the continuity 
Fhiska \& Augustina Kurniasih., Sch Bull, Jan, 2022; 8(1): $42-53$

of the supply chain, production, and marketing (Warren et al., 2005).

The faster the inventory turnover, the faster the inventory is converted to cash. The sooner cash is received, the greater the opportunity for the company to generate profits. Increasing profits give a positive signal so it increases the value of the company (Listianawati, 2019). The hypothesis results are in line with the research of Kurtaran (Kurtaran \& Kurtaran, 2015), which examined the BIST-100 index companies in 2008-2012 in Turkey. However, this study is not in line with Birgili \& Düzer (Birgili \& Düzer, 2010), who found that inventory turnover in the IMKB-10 Index in Turkey in 2001-2006 had a negative impact on firm value. It is not in line with research by Karaca \& Savsar (Karaca, n.d.), which found that inventory turnover in the food-beverage, tobacco, and base metal industries had a negative effect in Turkey for the period 20022009.

\section{4) GDP Moderates the Relationship of Investment Decisions to Firm Value}

The results show that GDP moderates the impact of investment decisions on firm value. Open systems theory explains that every decision or micro condition of the company is never separated from macro factors such as politics, economy, technology, culture, social, and others (LLC, 2006). An important component in the macro environment is Gross Domestic Product or GDP, which is the value of services and goods in a country produced by production factors belonging to both citizens and foreign countries (Sukirno, 2012). According to Tandelilin (Tandelilin, 2010), if economic conditions are good, it means that people's purchasing ability will increase; the greater the public's buying interest, the greater the GDP of a country. The results are in line with Karakus \& Bozkurt (Karakus \& Bozkurt, 2017), who examined 58 companies listed on the BIST-100 index 2006-2015 in Turkey.

GDP consists of public consumption, corporate investment, government spending, and export-import activities. An increase in GDP in a country can be caused by an increase in public spending or an increase in company investment. The increase in public consumption, one of which comes from public consumption of products produced by the pharmaceutical sub-sector. On the other hand, the increase in company investment can come from the investment activities of companies in the sub-sector of pharmacy. An increasing GDP indicates the country is experiencing expansion. This means that there are developments in the economy. Thus, GDP can moderate the effect of investment decisions on firm value.
Indonesia's Pharmaceutical sub-sector companies can increase investment where the investment comes from abroad (Reddy, 2000). Other countries are willing to invest when economic conditions or the country's GDP are in a developing position (Dudzevičiūtè et al., 2018). The results are in line with Fanelli \& Keifman (Fanelli \& Keifman, 2002) who examined the economy in Argentina in 1991-1998; Francis (Gitagia et al., 2020), who examined companies that listed on the Nairobi Securities Exchange Kenya for the term 2008-2016.

\section{5) GDP Moderates Market Penetration Relationship to Firm Value}

The results show that GDP does not moderate the effect of market penetration on firm value. Market penetration also does not directly influence the value of the company. These results indicate that the market penetration strategy has not been able to increase firm value. As the current Covid-19 pandemic causes market conditions to change rapidly, companies cannot rely solely on their existing market share in their efforts to attract consumers without changing their products or services according to current conditions. If the company has been able to develop new markets and/or products, then the company needs to maintain these markets so that consumers remain satisfied and loyal. Customer satisfaction and loyalty continue to increase the company's sales and eventually increase the company's value.

The economic level of a country also moderates the microenvironment in influencing firm value. Companies that choose to carry out a market penetration strategy must consider the economic conditions of the target country. This is important because if a country experiences a bad economic condition, such as a recession, then the country has lost its purchasing power (Kemenkeu RI, 2020). Thus, the company applies open system theory to be able to find out how conditions originate from the environment outside the company, one of which is by looking at the level of a country's economic condition or GDP. This study shows that without knowing a country's GDP is in good condition or vice versa, the company's efforts in carrying out a market penetration strategy have not been able to increase the value of the company. To increase the value of the company, it is important for companies to understand how the conditions of the company's micro/internal environment are before paying further attention to conditions that originate from outside the company. Companies must be more ready to accept market demand quickly and understand the needs of the products or services needed, so it is necessary to do other strategies to increase the value of the company. The results are not in line with Karakus \& Bozkurt (Karakus \& Bozkurt, 2017), who found that GDP in the BIST-100 Index in Turkey in 2006-2015 had a positive effect on firm value. Pasaribu (Pasaribu, 2017) found 
Fhiska \& Augustina Kurniasih., Sch Bull, Jan, 2022; 8(1): 42-53

GDP in the industry of food and beverage had a significant and positive effect on firm value. It is not in line with Traill (Traill, 2006), who found that GDP can moderate market penetration in supermarkets in America.

\section{6) GDP Moderates Inventory Turnover Relationship to Firm Value}

The results showed that GDP moderated the relationship between inventory turnover and firm value. Companies need to ensure how fast inventory turnover activities are to maintain the continuity of the supply chain, production, and marketing (Warren et al., 2005). The higher the inventory turnover rate, the faster the company sells merchandise converted into cash. This is because the public's demand for the company's products is high. This means that the products of the pharmaceutical sub-sector companies are accepted by the public. It can be seen from the pamdemic of Covid19 , where the demand for health products and services is increasing even in difficult economic conditions. Therefore, the company will be faster in generating profits and increasing firm value (Stice et al., 2004; Warren et al., 2005)

Based on the theory of open systems explains that the microenvironment of the company will always be affected by the macroenvironment. Different macroenvironmental conditions, especially during a pandemic filled with uncertainty, will have different effects on the relationship between inventory turnover as a component of the microenvironment on firm value (Robbins \& Coulter, 2012).

The macro-environment moderates the relationship between the microenvironment and company performance (Odhiambo Mudany et al., 2021). According to Banik \& Roy (Banik \& Roy, 2021), there is an important component in the macro environment, namely GDP. This component is considered important because it has a close relationship with the economy, politics, technology, monetary policy, social, and so on.

GDP consists of public consumption, corporate investment, government spending, and export-import activities. An increase in GDP in a country can be caused by an increase in public spending or an increase in the company's inventory turnover activity. One of the reasons for increasing public consumption is the pharmaceutical sub-sector. An increase in GDP indicates an increase in people's purchasing power. Public purchases of pharmaceutical products will increase the company's sales and will ultimately increase the company's value.

The company's strategy is to know the economic conditions or GDP of a country because it is able to provide a positive signal for companies in determining the right inventory to minimize the occurrence of shortages or excess inventories and is effective in increasing company value (Brigham \& Houston, 2013). The increase in the number of goods causes the economy to grow and increases the scale of the company's sales turnover because of the consumptive nature of society. With the sales turnover that increases, the company's profits also increase. Furthermore, if carried out by countries that have good economic conditions, the export-import process of raw materials and products or the high level of company inventory turnover activity will also increase, so that the faster the turnover of inventory into cash and generate profits will further increase the value of the company. The hypothesis results are in accordance with research by Karakus \& Bozkurt (Karakus \& Bozkurt, 2017), which found that GDP in the BIST-100 Index in Turkey in 2006-2015 had a positive effect on firm value; Pasaribu (Pasaribu, 2017) found that GDP in the sector of food and beverage industry listed on the IDX for the 2010-2015 period had a significant dan positive effect on firm value; Kurtaran (Kurtaran \& Kurtaran, 2015), who found that inventory turnover in the BIST-100 index in 2008-2012 in Turkey had a positive influence on firm value.

Of the three independent variables that have a significant effect on firm value, investment decisions have the greatest influence. Thus, company management needs to manage/allocate funds for acquisitions, business upgrades, or investments so that the value of the company will be even greater.

\section{CONCLUSIONS AND SUGGESTION}

According to the results of the analysis and discussion, it can be concluded as follows:

- Investment decisions positively and significantly impact the value of companies in the pharmaceutical sub-sector listed on the IDX in 2015-2020.

- Market penetration has no influence on the value of the pharmaceutical sub-sector companies listed on the IDX in 2015-2020.

- Inventory turnover has a significant and positive effect on the value of the pharmaceutical sub-sector companies listed on the IDX in 2015-2020.

- GDP acts as a quasi moderation. GDP has a direct effect as an independent variable and can strengthen the influence between the investment decision variables on the value of companies in the pharmaceutical sub-sector listed on the IDX in 2015-2020.

- GDP acts as no moderation. GDP does not have a direct effect as an independent variable and cannot moderate the effect of market penetration on the value of companies in the pharmaceutical subsector listed on the Indonesia Stock Exchange in 2015-2020. 
Fhiska \& Augustina Kurniasih., Sch Bull, Jan, 2022; 8(1): $42-53$

- GDP acts as a quasi moderation. GDP has a direct effect as an independent variable and strengthens the relationship between the inventory turnover variable and the value of the pharmaceutical subsector companies listed on the IDX in 2015-2020.

Here is Some suggestions related to the results of this research: 1) For the Company. The most important thing that companies need to do is to optimize investment activities to enlarge the company. Then second, the company can maximize efforts in managing how fast inventory turnover activities are. And it is important to see how the current economic condition is because it has been proven to increase the company value; 2) For Investors. Investors who intend to invest in shares of companies in the pharmaceutical sub-sector and take the value of the company into consideration need to pay attention to the value of fixed assets. Investors should analyze the condition of the company first through published financial reports; 3) For Further Researchers. Because in this study, market penetration does not have an effect either directly or after the moderation process, the authors suggest looking at other factors by looking at the obstacles that occur after the sale of products or services, such as satisfaction and loyalty. Because in this sector, continuous efforts are needed to carry out innovation, renewal, and other medical devices.

\section{REFERENCES}

- Adamik, A., \& Sikora-Fernandez, D. (2021). Smart organizations as a source of competitiveness and sustainable development in the age of industry 4.0: Integration of micro and macro perspective. Energies, 14(6). https://doi.org/10.3390/en14061572

- Adams, P., Bodas Freitas, I. M., \& Fontana, R. (2019). Strategic orientation, innovation performance and the moderating influence of marketing management. Journal of Business Research, 97, 129-140. https://doi.org/10.1016/j.jbusres.2018.12.071

- Afzal, A., \& Rohman, A. (2012). Pengaruh Keputusan Investasi, Keputusan Pendanaan dan Kebijakan Deviden terhadap Nilai Perusahaan. Diponegoro Journal of Accounting, 1(2), 1-9.

- Akerlof, G. A. (1970). The Market for "Lemons": Quality Uncertainty and the Market Mechanism. The Quarterly Journal of Economics, 84(3), 488500. https://doi.org/10.2307/1879431

- Ayem, S., \& Nugroho, R. (2016). Pengaruh Profitabilitas, Struktur Modal, Kebijakan Deviden, dan Keputusan Investasi terhadap Nilai Perusahaan. Jurnal Akuntansi, 4(1), 31-39.

- Banik, B., \& Roy, C. K. (2021). Effect of exchange rate uncertainty on bilateral trade performance in SAARC countries: a gravity model analysis. International Trade, Politics and Development,
5(1), 32-50. https://doi.org/10.1108/itpd-08-20200076

- Birgili, E., \& Düzer, M. (2010). Finansal Analizde Kullanılan Oranlar ve Firma Değeri İlișkisi: İMKB'de Bir Uygulama. Muhasebe ve Finansman Dergisi, 46, 74-83.

- BPS. (2021). Badan Pusat Statistik.

- Brigham, E. F., \& Houston, J. F. (2013). Dasar dasar manajemen keuangan (11th ed.). Salemba Empat.

- CRS. (2021). CRS_Home.

- Cumming, T. G., \& Worley, D. G. (2005). Organization Development and Change: General Introduction to Organization Development.

- Deloitte. (2021). deloitte.

- Dudzevičiūtè, G., Šimelytè, A., \& Liučvaitienè, A. (2018). Government expenditure and economic growth in the European Union countries. International Journal of Social Economics, 45(2), 372-386. https://doi.org/10.1108/IJSE-12-20160365

- EFPIA. (2012). EFPIA Homepage.

- Fama, E. F. (1978). The Effects of a Firm's Investment and Financing Decisions on the Welfare of Its Security Holders. The American Economic Review, 68(3), 272-284.

- Fanelli, J. M., \& Keifman, S. (2002). Finance and Changing Patterns in Developing Countries. Journal of Finance and Accounting, 15(4), 143 171.

- Fauziah, A., \& Asandimitra, N. (2018). Pengaruh Keputusan Investasi, Keputusan Pendanaan, Kebijakan Deviden dan Profitabilitas terhadap Nilai Perusahaan (Studi pada Perusahaan Industri Dasar dan Kimia yang Terdaftar di BEI Periode Tahun 2012-2016). Jurnal Ilmu Manajemen, 6(3), 84-92.

- $\quad$ Fidhyatin, S. K., \& Dewi, N. H. U. (2012). Analisis Nilai Perusahaan, Kinerja Perusahaan, dan Kesempatan Bertumbuh Perusahaan terhadap Return Saham pada Perusahaan Manufaktur yang Listing di BEI. The Indonesian Accounting Review, 2(2), 203-214.

- Gitagia, F. K., Wamugo, L., \& Omagwa, J. (2020). Dividend Decisions, Economic Growth and Firm's Value of Firms Listed at Nairobi Securities Exchange Kenya. Research Journal of Finance and Accounting, 11(18), 41-48. https://doi.org/10.7176/rjfa/11-18-06

- Hidayat, R. (2010). Keputusan Investasi dan Financial Constraints: Studi Empiris pada Bursa Efek Indonesia. Buletin Ekonomi Moneter Dan Perbankan, 12(4), 457-479.

- Holm, M., Kumar, V., \& Rohde, C. (2012). Measuring customer profitability in complex environments: An interdisciplinary contingency framework. Journal of the Academy of Marketing 
Fhiska \& Augustina Kurniasih., Sch Bull, Jan, 2022; 8(1): $42-53$

Science, $\quad 40(3), \quad 387-401$. https://doi.org/10.1007/s11747-011-0263-4

- Husnan, S., \& Pudjiastuti, E. (2012). Dasar-Dasar Teori Manajemen Keuangan.

- IDX. (2021). PT Bursa Efek Indonesia.

- ILO. (2015). International Labour Organization.

- Karaca, S. S. (n.d.). The effect of financial ratios on the firm value: Evidence from Turkey THE EFFECT OF FINANCIAL RATIOS ON THE FIRM VALUE: EVIDENCE FROM TURKEY 1. https://www.researchgate.net/publication/28879640 8

- Karakus, R., \& Bozkurt, İ. (2017). The Effect of Financial Ratios and Macroeconomic Factors on Firm Value: An Empirical Analysis in Borsa Istanbul The Effect of Financial Ratios and Macroeconomic Factors on Firm Value: An Empirical Analysis in Borsa Istanbul. RSEP International Conferences on Social Issues and Economic Studies. https://doi.org/10.19275/RSEPCONFERENCES09 1

- Kemenkeu RI. (2020). Kementerian Keuangan RI.

- Kemenperin. (2020a). Kementerian Perindustrian.

- Kemenperin. (2020b). Kementerian Perindustrian.

- Kieso, D. E., Weygandt, J. J., \& Warfield, T. D. (2011). Intermediate Accounting, Problem Solving Survival Guide (Vol. 2). John Wiley \& Sons.

- Kotler, P., \& Keller, K. L. (2016). Marketing Management 15th edition (15th ed.). New Jersey Pearson Prentic Hall, Inc.

- Kumparan. (2018). kumparan.com - Platform Media Berita Kolaboratif, Terkini Indonesia Hari Ini. kumparan.com

- Kurniasih, B., \& Ruzikna. (2017). Pengaruh Struktur Modal dan Keputusan Investasi Terhadap Nilai Perusahaan pada Industri Makanan dan Minuman yang Terdaftar di BEI. JOM FISIP, 4(2), 1-14. www.idx.co.id

- Kurtaran, A., \& Kurtaran, A. T. (2015). FINANSAL ORANLAR İLE FIRMA DEĞERİ İLISSKISİ: BIST'TE BİR UYGULAMA. Global Journal of Economics and Business Studies, 4(8), 35-45. http://dergipark.ulakbim.gov.tr/gumusgjebs/

- Lévay, P. Z., Drossinos, Y., \& Thiel, C. (2017). The effect of fiscal incentives on market penetration of electric vehicles: A pairwise comparison of total cost of ownership. Energy Policy, 105, 524-533. https://doi.org/10.1016/j.enpol.2017.02.054

- Listianawati, M. (2019). Pengaruh PerputaranPersediaan, Pertumbuhan-Penjualan Dan Ukuran Perusahaan Terhadap Profitabilitas-Perusahaan (Studi Kasus Pada Perusahaan Sub Sekor Perdagangan Eceran Yang Terdaftar Di Bursa Efek Indonesia Pada Tahun 2013-2017).

- $\quad$ LLC. (2006). Authenticity Consulting, LLC.
- Mbithi, B., Muturi, W., \& Rambo, C. (2017). Macro environment moderating Effects on Strategy and Performance. Haya: The Saudi Journal of Life Sciences, 2(5), https://doi.org/10.21276/haya

197-209.

- McConnell, J. J., \& Muscarella, C. J. (1985). Corporate capital expenditure decisions and the market value of the firm. Journal of Financial Economics, 14(3), 399-422.

- McKinsey. (2021). McKinsey \& Company _ Global management consulting.

- $\quad$ Michael, S. (1973). Job market signaling. 87(3).

- Mishra, P. K., \& Mishra, S. K. (2020). Corona Pandemic and Stock Market Behaviour: Empirical Insights from Selected Asian Countries. Millennial Asia, 11(3), 341-365. https://doi.org/10.1177/0976399620952354

- Muriithi, R. M., \& Paul, W. (2020). Market Penetration Strategy and Performance of Agrochemical Companies in Nakuru County. Stratford Peer Reviewed Journals and Book Publishing, 4(4), 23-33.

- Mutia, S. (2013). An Investigation Into Internal growth Strategies Effect on Financial Performance of Commercial Banks (A Case Study of Equity Bank in Nairobi)

- Mwangi, E. W., \& Gakobo, J. (2018). Growth strategies and performance of selected milk processing companies in Kenya. International Journal of Contemporary Aspects in Strategic Management, 2(1), 158-172.

- Myers, S. C., \& Majluf, N. S. (1984). Corporate financing and investment decisions when firms have information that investors do not have. Journal of Financial Economics, 13(2), 187-221. https://doi.org/https://doi.org/10.1016/0304405X(84)90023-0

- Najmudin. (2011). Manajemen Keuangan, and Aktualisasi Syar'iyyah Modern. Andi Offset.

- Nduki, M. E. (2016). Growth Strategies and Performance of Insurance Firms in Kenya.

- Numa, J. A. (2013). The Relationship Between Product Diversification and Bussiness Growth in The Banking Industry in Kenya The Case of CoOperative Bank of Kenya.

- Nurlela, \& Islahudin. (2008). Pengaruh Corporate Social Responsibility terhadap Nilai Peusahaan dengan Prosentase Kepemilikan Manajemen sebagai Variabel Moderating.

- Odhiambo Mudany, J., Ngala, M., \& Gituro, W. (2021). Moderating Effect of Macro Environment on the Intervening Effect of Capital Structure on the Relationship Between Strategy Implementation and Performanceof Energy Sector Institutions in Kenya. African Journal of Emerging Issues (AJOEI). Online ISSN, 3, 67-95.

- Pasaribu, D. (2017). Impact of Fundamental, Risk and Demography on Value of the Firm. IOSR 
Journal of Economics and Finance, 08(02), 09-16. https://doi.org/10.9790/5933-0802040916

- Porter, M. E. (2007). TECHNOLOGY AND COMPETITIVE ADVANTAGE. The Journal of Bussiness Strategy.

- Rahmayani, D., \& Oktavilia, S. (2020). Does the Covid-19 pandemic affect the stock market in Indonesia? Jurnal Ilmu Sosial Dan Ilmu Politik, 24(1), 33-47. https://doi.org/10.22146/JSP.56432

- Reddy, J. N. (2000). Analysis of functionally graded plates. In INTERNATIONAL JOURNAL FOR NUMERICAL METHODS IN ENGINEERING Int. J. Numer. Meth. Engng (Vol. 47).

- Robbins, P. S., \& Coulter, M. K. (2012). Management. Prentice Hall.

- $\quad$ Sindhu, M. I., Hashmi, S. H., \& Ul Haq, E. (2016). Impact of ownership structure on dividend payout in Pakistani non-financial sector. Cogent Business and Management, 3(1). https://doi.org/10.1080/23311975.2016.1272815

- Slater, S. F., \& Narver, J. C. (1995). Market Orientation and the Learning Organization. Journal of $\quad$ Marketing, 59(3), 63. https://doi.org/10.2307/1252120

- $\quad$ Stice, J. D., Stice, E. K., \& Skousen, K. F. (2004). Akuntansi intermediate: Intermediate accounting . Salemba Empat.

- Subramanyam, K. R. (2014). Financial statement analysis.

- Sukirno, S. (2012). Makro ekonomi Teori pengantar edisi 3 (3rd ed.). Raja Grafindo Persada.
- Sutrisno, H. (2009). Manajemen keuangan teori, konsep dan aplikasi. Ekonosia.

- Tandelilin, E. (2010). Dasar-dasar Manajemen Investasi.

- Traill, W. (2006). The Rapid Rise of Supermarkets? Development Policy Review, 24, 163-174. https://doi.org/10.1111/j.14677679.2006.00320.x

- Vranakis, S., \& Chatzoglou, P. (2011). A Conceptual Model for Machinery \& Equipment Investment Decisions. International Journal of Business and Management, 7(1). https://doi.org/10.5539/ijbm.v7n1p36

- Wahyuati, A., \& Safitri, N. (2015). Pengaruh Struktur Modal dan Keputusan Investasi terhadap Profitabilitas dan Nilai Perusahaan. Jurnal Ilmu Dan Riset Manajemen, 4(2), 1-17.

- Warren, C. S., Reeve, J. M., \& Fess, P. E. (2005). Pengantar Akuntansi, Edisi 21. Jakarta Salemba Empat. (21st ed.). Salemba Empat.

- Wiagustini, N. L. P. (2013). Manajemen Keuangan. Bali Udayana University Press.

- World Bank. (2020). World Bank Group International Development, Poverty, \& Sustainability.

- Yuliani, R., \& Hadi, D. A. (2020). The Factors of Capital Expenditure, Leverage, Profitability, Company Value Affect the Property Sector. Solid State Technology, 63(3). www.solidstatetechnology.us 